\title{
Pitfalls in the Implementation of District Assemblies' Skills Training Program for the Informal Sector: A Case Study of Ghana
}

\author{
Owusu A. Joyce ${ }^{1} \&$ Liu Xinyan ${ }^{1}$ \\ ${ }^{1}$ College of Economics and Management, Oversea Education College, Nanjing Tech University, Jiangsu, China \\ Correspondence: Owusu A. Joyce, College of Economics and Management, Nanjing Tech University, Jiangsu, \\ China.E-mail: owusuasika12@yahoo.com
}

Received: September 7, 2017

Accepted: October 2, 2017

Online Published: October 18, 2017

doi:10.5539/ijbm.v12n11p242

URL: https://doi.org/10.5539/ijbm.v12n11p242

\begin{abstract}
The informal sector plays a very significant role in the economy of many developed and developing countries across the globe. Hence many African countries have, as part of their national development agenda, made conscious efforts aimed at training their nationals, who were unable to pursue formal sector employment through higher education, for the informal sector trade. Ghana has done this for some decades now but not at a success that it wants. Using descriptive statistics, this paper seeks to uncover the pitfalls in the implementation of skills training programs conducted by the district assemblies of Ghana and subsequently offer solutions to the pitfalls. To harness the needed information, questionnaire and interview were employed in gathering data from the subjects. The paper has succeeded to identify 20 pitfalls categorized as financial, technical and other factors. A model has also been suggested for the combat of these pitfalls.
\end{abstract}

Keywords: district assembly, Ghana, informal sector, pitfalls, skills training program

\section{Introduction}

For some time now, unemployment among the youth has being a major challenge facing the Ghanaian community. This story is no different in many other African nations and that of other continents as well. The causes of this unemployment situation are both internal and external. A major cause of the unemployment among the youth is the high dropout rates among Junior High School leavers transition to Senior High School either due to poor academic performance or inability of parents to finance secondary and tertiary education. These dropouts in many cases are unable to access formal employment in the formal sector of the economy.

In such situations, the informal sector plays a critical role in offering employment to those unable to pursue formal sector employment. Tshuma et al., (2013) and McLaughlin (1990) have defined the informal sector as consisting of small-scale, self-employed activities (with or without hired workers), typically at a low level of organization and technology with the primary objective of generating employment and incomes. Seshamani (1990), further adds to this definition by stating that this sector is comprised of all those activities which generate incomes that go unrecorded in the formal accounts of the national economy. Thus, the informal sector covers a wide range of labour market activities that chain's two groups of different nature: (1) the informal sector is formed by coping behavior of individuals and families in economic environment where earning opportunities are scarce and (2) the informal sector is a product of rational behavior of entrepreneurs that desire to escape state regulations.

What makes informal trading attractive worldwide is that the sector typically requires relatively small capital which in most cases comes from the traders' own personal savings. The sector is also not homogenous and can come in almost any form. For example, it can cover the (i) sale of cooked and uncooked foods which reflects the dominance of agriculture in the economy; (ii) service sector which includes barber shops, general stores (or kiosks), open-air garages and sale of used clothing; and (iii) the manufacturing of wood and metal products notably furniture and related household metal-based goods (Tshuma et al, 2013). On this line of thought, Obwocha (2006) noted that, women dominate the less profitable food and beverages sub-sector whereas men have a near monopoly in the more profitable manufacturing enterprises such as the production of household 
metals, goods and furniture. Whilst most of those engaging in this sector are those that could not be accommodated within the formal sector either due to their lack of education or skills. However, this paper solely concentrates on the vocational training skills such as sewing and garment making, construction, crafts, catering services, hairdressing, shoemaking, farming, soap making, carpentry and joinery, mechanical/auto/electrical repairs and network, batik tie and dye, kente weaving, refrigeration and air conditioning repairs. All these and more are categorized under the district assemblies vocational skills training programs for the informal sector, however, other initiatives seek to equip those who wish to be involved in ongoing and future projects with specific skills they need to make them employable.

Over the years, successive governments have embarked on skills development training programs for the unemployed youth. Boadu, Dwomo-Fokua, Boakye \& Kwaning (2014) sought to the relationship between training and development, and employee performance. Results from the data analysis indicated that significant relationship exist between training and development and job satisfaction. Finally, the study revealed that management and employees face peculiar problems during training and development exercises. Management complained about funds whilst employees' expressed concern about the time allotted to various training and development programs. In a related study, Pongo, Effah, Osei-Owusu, Obinnim \& Sam (2014) presented a survey study aimed at finding out how skills training programs are achieving their purpose of increasing access of young people to skills and empowerment for productive employment. The results indicated that the skills training programs were helpful to communities in securing suitable employment that allows them to generate income with the social, family and financial constraints that they face in their communities. The study concludes that the social and economic status of beneficiaries have been improved positively. Enu-Kwesi \& Asitik (2012) held the opinion that people require some form of training and education in order to develop the relevant skills, knowledge and attitudes requisite for meaningful employment. Enu-Kwesi \& Asitik (2012) presented a paper that examines the links between unemployment situation and youth enterprise in the Ajumako-Enyan District in the central region of Ghana. The authors found that the youth of the district have entrepreneurial skills, but low educational attainment has been a challenge to training. The authors therefore suggested that the District Assembly should promote skills training and entrepreneurship in the educational institutions within the district.

However, in agreement with Debrah (2007), trainees of such programs have, on many occasions, failed to set themselves up through the informal sector. Hence, this paper seeks to investigate skills training programs aimed at creating jobs for people in the informal sector.

\subsection{Objectives}

The objectives of this study is:

1. To investigate problems facing the implementations of District Assemblies skills training programs for the informal sector.

2. To propose a solution to the problems being faced by the District Assemblies in implementing of skills training programs for the informal sector training programs

\section{Methodology}

\subsection{Description of the Study Area}

The study area is Ghana which is a West African country. The country shares its northern, eastern and western boundaries with Burkina Faso, Togo and Cote D'voire respectively. Its southern part is the Gulf of Guinea. Geographically, Ghana is estimated to be the closest country to the center of the earth. The Republic of Ghana has 216 Metropolitan/Municipal/District Assemblies headed by Chief Executives. Fig. 1 (Ghana map of Africa ho) depicts the location of the study area.

Ghana has a relatively well organized informal sector as compared to other African countries. This can be attributed to the maiden informal sector research conducted on Ghana by Keith Harth (1973) and the efforts of successive and present governments. Hence, the author is of the view that in addition to addressing challenges bedeviling Ghana's informal sector, findings will be applicable to other African countries as well. 


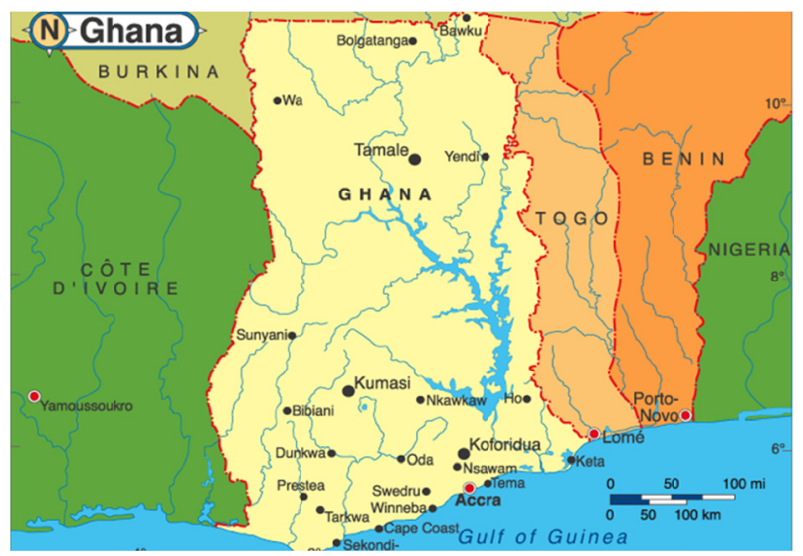

Figure 1. A Map Showing Location of Ghana

Source: www.map/andia.com/ghana/volta/ho

\subsection{Data Collection Procedure}

Semi-structure questionnaire and interview were the main techniques used for data collection. Interviews which were also conducted with both the youths and some DA officers to obtain additional but necessary qualitative data. Secondary data was through review of theoretical literatures sourced from books and scholarly journals, internet and conference papers. Purposive sampling technique was found useful in the selection of fifty respondents from the study population. Secondary data were large through scholarly articlles.

\subsection{Study Population}

The study population consists of participants in the informal sector, district assembly officials mandated to organize and offer skills apprenticeship programs for the informal sector, government of Ghana and its funding partners. The reason for the inclusion of these entities was for the attainment of balanced representation of issues and opinions within the informal sector.

\section{Results and Discussions}

\subsection{Pitfalls in the implementation of District Assemblies Skills Training Programs}

Table 1 presents pitfalls which pose various hindrances to the successful implementation of skills training programs at the various district assemblies in Ghana.

Table 1. Pitfalls in the implementation of District Assemblies' skills training programs

\begin{tabular}{lllll}
\hline S/N & FINANCIAL FACTORS & $\begin{array}{l}\text { RESPONSE } \\
\text { RATE }\end{array}$ & $\begin{array}{l}\text { TOTAL } \\
\text { RESPONSE }\end{array}$ & PERCENTAGE (\%) \\
\hline 1. & Inadequate funding & 12 & 50 & 24 \\
2. & Inadequate training tools & 15 & 50 & 30 \\
3. & Delay in the release of funds & 17 & 50 & 34 \\
4. & Delay in the payment of trainees allowance & 19 & 50 & 38 \\
5. & Lack of start-up capital after training & 18 & 50 & 46 \\
6. & $\quad$ Trainees inability to access bank loans individually & 24 & 50 & $\mathbf{4 0}$ \\
7. & $\quad \begin{array}{l}\text { No ready market for trainees product and } \\
\text { service }\end{array}$ & $\mathbf{2 0}$ & $\mathbf{5 0}$
\end{tabular}




\begin{tabular}{|c|c|c|c|c|}
\hline & TECHNICAL FACTORS & & & \\
\hline 8. & Low level of technology & 11 & 50 & 22 \\
\hline 9. & $\begin{array}{l}\text { Unavailability of laid down structures in the } \\
\text { vocational skills training }\end{array}$ & 10 & 50 & 20 \\
\hline 10. & $\begin{array}{l}\text { Inability of district assembly to retain and hire } \\
\text { qualified and experienced professionals }\end{array}$ & 20 & $\mathbf{5 0}$ & 40 \\
\hline 11. & Inexperienced trainers & 3 & 50 & 6 \\
\hline 12. & $\begin{array}{l}\text { Lack of in-service training for district assembly } \\
\text { officers }\end{array}$ & 20 & $\mathbf{5 0}$ & 40 \\
\hline 13. & $\begin{array}{l}\text { Lack of monitoring and evaluation by funding } \\
\text { bodies }\end{array}$ & 8 & 50 & 16 \\
\hline \multirow[t]{2}{*}{14.} & Insufficient training for trainees & 15 & 50 & 30 \\
\hline & OTHER FACTORS & & & \\
\hline 15. & $\begin{array}{l}\text { Trainees inability to follow instruction due to low } \\
\text { illiteracy }\end{array}$ & 13 & 50 & 26 \\
\hline 16. & Bureaucracy & 21 & $\mathbf{5 0}$ & 42 \\
\hline 17. & Lack of cooperation by beneficiary communities & 17 & 50 & 34 \\
\hline 18. & $\begin{array}{l}\text { Politicization of policies by both government and } \\
\text { society }\end{array}$ & 16 & 50 & 32 \\
\hline 19. & Poor learning environment & 11 & 50 & 22 \\
\hline 20. & Lack of motivation for trainees & 16 & 50 & 32 \\
\hline
\end{tabular}

Table 1 reveals 20 pitfalls in the implementation of district assemblies' skills training projects in Ghana. Among the leading pitfalls are trainee inability to access bank loan at the personal level, bureaucracy, inability of district assembly to retain and hire qualified and experienced professionals, lack of in-service training for district assembly officers and no ready market for trainee products and services.

Multiple factors account for these pitfalls. Some of the factors are planning and implementation related. Others are also due to lack of proper coordination of such training programs at the district assemblies. Thus, addressing the aforementioned pitfall in isolation will in no significant terms address the problem of making skills training programs better. We therefore propose a holistic model which when strictly followed would yield the needed results for addressing the teaming youth unemployment in Ghana.

\subsection{Proposed Solution to the Pitfalls in the Implementation of DAs Skills Training Programs}

Figure 2 represents proposed solution model to remedy the pitfalls outlined in Table 1. The succeeding paragraphs under this subsection explain how the model works and also identifies the key players in each stage where needed. 


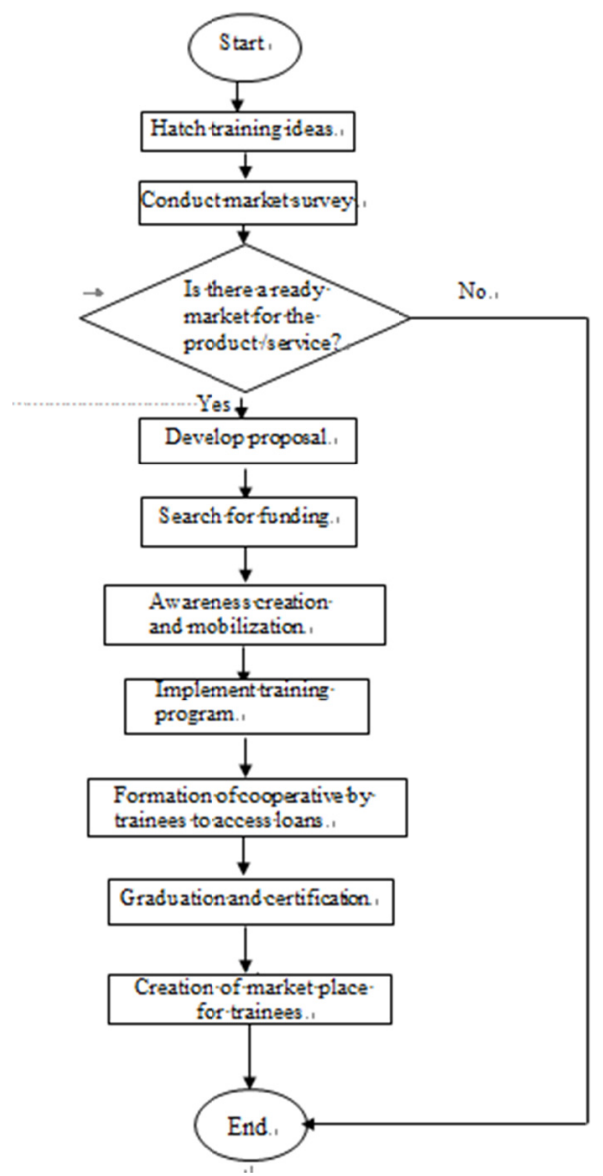

Figure 2. Proposed Solution to the Pitfalls in the Implementation Flowchart

\section{Stage 1: Hatch Training Idea}

This stage is the first in the life cycle of a skills training program at the District Assembly (DA). It refers to a point where project ideas are conceived. The idea can originate from sources such as the NGOs, the DA itself, government and prospective beneficiary communities. However brilliant idea(s) may appear initially, it must be subjected to scrutiny to ensure value for money.

Stage 2: Conduct Idea Feasibility Study

This stage should be an assessment of the practicality of the idea conceived at stage 1 . This stage must include market, technical and other feasibility study to determine feasibility and benefits to the targeted trainees and the society at large. Such feasibility study must be carried out by the planning department of the DA. However, this can be done in conjunction with appropriate stakeholders. This stage may appear needless to say, but a field survey conducted during this research revealed that non-existent markets for products and services rendered by trainees afterwards. The training idea must move to the next stage of the project life cycle only if it is feasible otherwise the idea should be shelved.

\section{Stage 3: Develop Skills Training Proposal}

This stage refers to the actual proposal development for the idea and must be done by the planning department of the DA. At this stage, the planning department must do a proper Strength, Weakness, Opportunity and Threat (SWOT) analysis. This, if properly done, will assist the planning department to determine exactly what is needed for the execution of the project and subsequently help in the budgeting process. A personal communication with some trainees revealed that there have been instances where projects have failed partly because certain logistics needed for the training were not provided. Such lapses are related to poor planning. Most of the DA assemblies are not financially sound enough to fully fund their self-initiated projects. Thus, external funding becomes important. 


\section{Stage 4: Search for Funding}

Here, the planning department searches for funding from the funding bodies interested in the training area. The DA must have an officer in charge of grant search. Such an officer can come from either the planning unit or the finance office of the assembly. The said officer will serve as a contact person for the assembly on all grant applications to ensure effective correspondence between the assembly and the funding bodies.

\section{Stage 5: Create Awareness and Mobilize}

Awareness creation and mobilization becomes the next stage after having secured funds for the intended training project. This stage is the responsibility of the Community Development Department (CDD) of the DA. The main objective of this stage is to create awareness about the program to the constituents communities of the DA and subsequently mobilize interested persons for the training. For easy and effective mobilization, we propose that the Community Development Department must involve stake holders such as the assembly members, community chiefs, unit committees and youth leaders to ensure proper and non-politicization training at the grass root level.

At this stage, the CDD must spell out the details of the training program to the prospective trainees so that people who are really interested get selected in the end. Often times, trainees are lured into such programs with unfulfilled promises resulting in high trainee attrition rate.

\section{Stage 6: Implement Training Program}

Once the mobilization and awareness creation of the idea by the Community Development officers and the interested prospective are grouped according to their preferred skills, then there is the need to start implementation. This is the stage where the skills training begins. However, before that, the Planning Department must meet with the heads of all stakeholder department of the DA and the funding body to discuss details of implementation process and milestones to be achieved at various stages. Discussions on the need for the formation of cooperatives by the trainees to access bank loans can be initiated at this stage and hopefully assign an officer to assist trainees.

\section{Stage 7: Form Cooperatives}

The officer assigned in stage 6 at this stage must serve as liaison officer between the commercials banks and the trainees who want to access bank loan. The officer in charge must contact the banks to find out modalities and interest rate of the various banks and in the end help the trainees to choose the bank with a better offer. The officer at the same time can help members in the drafting of constitution and any other documentation that may be necessary.

\section{Stage 8: Graduate and Certificate Trainees}

This stage refers to a point where trainees have successfully gone through the training program and requires to be graduated and certificated. Normally graduation ceremonies are organized for such events by the DA. Much as we appreciate the importance of such ceremonies, we further suggest that such ceremonies must also capture an educational talk on entrepreneurship, all in the spirit of making the trainee succeed afterwards.

A novel suggestion here is that the DA assembly officer in charge of fund raising can also mobilize funds through cooperate bodies and philanthropists for the purpose of purchasing some essential tools for the graduating trainees. This move, will also help reduce the difficult to access loans from banks.

Stage 9: Create Market for Trainees

To a large extent, businesses and entrepreneurs thrive on the availability of market of competitive markets for goods and services. But, there have been instances where markets simply do not exist for the goods and services offered by entrepreneurs created out of such skills training programs. This came to light through personal conversation with individuals who have benefited from such training programs. To this end, we proposed that the district assemblies in their market development plan should zone a place for such businesses and also offer them some tax exemptions in the initial stages of their businesses.

\section{Conclusions}

This study sought to identify the pitfall in the implementation of skills training programs at the district assemblies in Ghana and subsequently offer solutions to the pitfalls. The pitfalls are identified and categorized as financial, technical and other factors. We were of a firm belief that the identified problems should not be tackled in isolation but instead be solved through a holistic model depicted in Fig. 2. 


\section{Acknowledgements}

Apart from the efforts of myself and my co-author (my supervisor), the success of any projects depends largely on the encouragement and guidelines of many others. I take this opportunity to express my gratitude to the people who have been instrumental in the successful completion of this project; Mr. Ben Ayawali, Mr. Frimpong Kyeremeh, Mr. Abedi Attiemoh, Mr. Bright Dzinyegbe, Nii Amartey Amartei, Miss Harriet Kesewa Nyanor and Madam Beatrice Appiah.

We would like to show our greatest appreciation to Nanjing Tech University, Oversea Education College and the College of Economic and Management. We say thank you for their tremendous support and help. Also, we want to say thank you to Mr. Albert Appiah and Mr. Attigah Samuel Doe Kwasi for their motivation, assistance and encouragement, without their encouragement and guidance this project would not have materialized. The guidance and support received from all the members who contributed, we are grateful for their constant support and help. The authors wishes to express their love and gratitude to their families, for their understanding and endless love.

\section{References}

Boadu, H. Dwomo-Fokuo, E., Boakye, J. K., \& Kwaning, C. O. (2014). Training and Development and Development: A tool for Employee Performance in the District Assemblies Ghana. International of Education and Research, 2(5), 513-522.

Debrah, Y. A. (2007). Promoting the informal sector as a source of gainful employment in developing countries: insight from Ghana. International Journal of Human Resource Management, 18, 1063-1084. http://dx.doi.org/10.1080109585190701321716

Enu-Kwesi, F., \& Asitik, A. J. (2012). Youth Employment and Entrepreneurial Skills Development in the Ajumako-Enyan-Essan District of Ghana. Ghana Journal of Development Studies, 9(1), 74-87.

Ghana Map (nd.). Retrieved from http://www.map/andia.com/ghana/volta/ho

Hart, K. (1973). Informal Income Opportunities and the Urban Employment in Ghana. Journal of Modern African Studies, 11(1), 61-89.

Obwocha, H. (2006). Small Businesses and Economic Growth in Eastern Africa. A speech read Obwocha, H Minister for Planning and National Development, Republic of Kenya, to the IFC Credit Reporting Conference, Nairobi.

Pongo, N. A., Effah, B., Osei-Owusu, B., Obinnim, E. \& Sam, F. K. (2014), The Impact of TVET in Ghana's Socio-Economic Development: A Case Study of ICCES TVET Skills Training in Two Regions of Ghana, American Journal of Comptemporary Research, 14(1), 185-192.

Seshamani, V. (1990). The Informal Sector in Zambia: An Overview of Issues, Problems and Prospects. University of Zambia, Lusaka, Zambia. Retrieved from http:/www.hsrcpress.ac.za/downladpdf.pdf

Thomas, W. H. (1989). South Africa's Growing Black Market. Challenges for the 1990s. Speech at the Spotlight on the Black Market Conference, sponsored by the Small Business Development Centre in Johannesburg, South Africa.

Tshuman, M. C., \& Jari, B. (2013). The informal sector as a source of household income: the case of Alice town in the Eastern Cape Province of South Africa.

\section{Copyrights}

Copyright for this article is retained by the author(s), with first publication rights granted to the journal.

This is an open-access article distributed under the terms and conditions of the Creative Commons Attribution license (http://creativecommons.org/licenses/by/4.0/). 